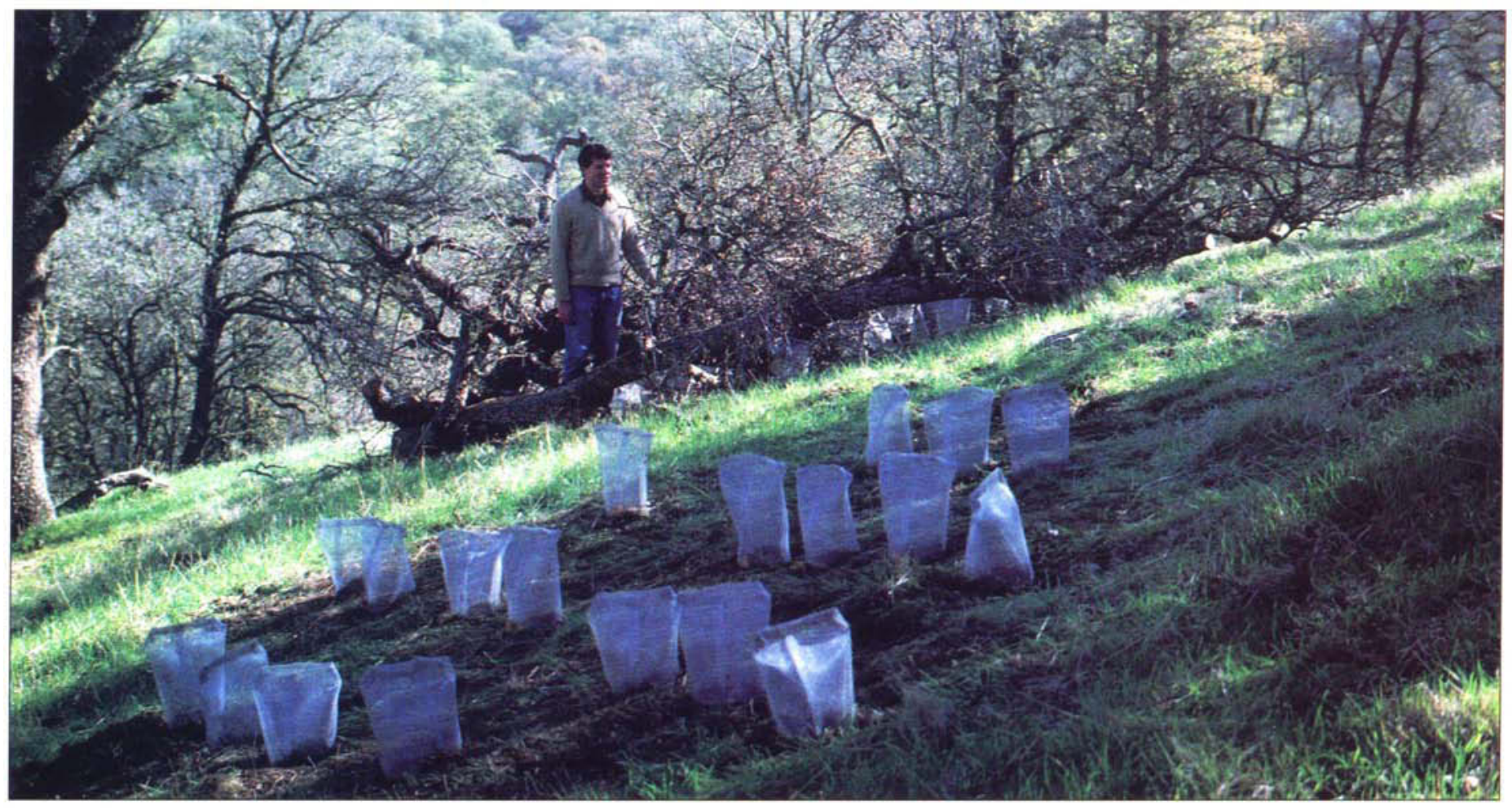

In a 12-year study of protection methods for oak seedlings, half of the acorn plantings were protected with aluminum cages. Plantings were also covered with brush, background, and left uncovered, foreground.

\title{
Brush piles and mesh cages protect blue oak seedlings from animals
}

\author{
William H. Weitkamp $\square \quad$ William D. Tietje $\square \quad$ Justin K. Vreeland
}

\begin{abstract}
Oak tree branches piled over acorn-seeded blue oaks were tested as protection against cattle and deer. The piles remained in place and apparently free of cattle and deer for 8.5 years, until a wildfire destroyed the branches. Before the fire in 1996, seedlings in the brush had similar survival rates but grew significantly faster than seedlings with no brush. Seedling survival and growth rates declined sharply after the fire, although the surviving trees regained their prefire heights in 3 years. Cages made of aluminum window screening, as protection from small animals, significantly increased seedling survival and growth rates. Growth rates over the 12 years of the trial averaged only about 0.5 to 1 inch per year.
\end{abstract}

$A_{\text {s agriculture and development }}^{\text {encroach on California's } 10 \text { mil- }}$ lion acres of oak woodlands, offsetting those losses will depend on the success of tree-planting projects and the natural regeneration of seedlings. Large animals such as deer and livestock, and small animals such as squirrels, gophers and rabbits, can damage entire plantings or natural stands of unprotected oak seedlings. As oak regeneration projects become more common, their widespread success will depend on economical and practical methods of protecting seedlings from animal damage.

Fenced enclosures keep out larger animals but are expensive for greater acreages or individual tree protection on a large scale. To keep out small animals, metal or plastic mesh materials can be used to encircle individual trees. Plastic mesh protectors are inex- pensive and provide protection to a height of 6 to 24 inches. If grasshoppers or other insects are a threat, the finer mesh provided by aluminum screening is necessary.

A combination of mesh protectors around individual trees and an inexpensive material to protect against large animals would increase the feasibility of large-scale regeneration projects. Tree branches often are available at regeneration sites and can be piled over seeded areas or individual plantings. Brush piles, as physical barriers, have also been observed to provide effective protection from large browsing animals.

\section{Brush and cage treatments}

To test two low-cost tree-protection practices, we chose a range area on a north-facing hillside wooded with blue oaks, on the Avenales Ranch 


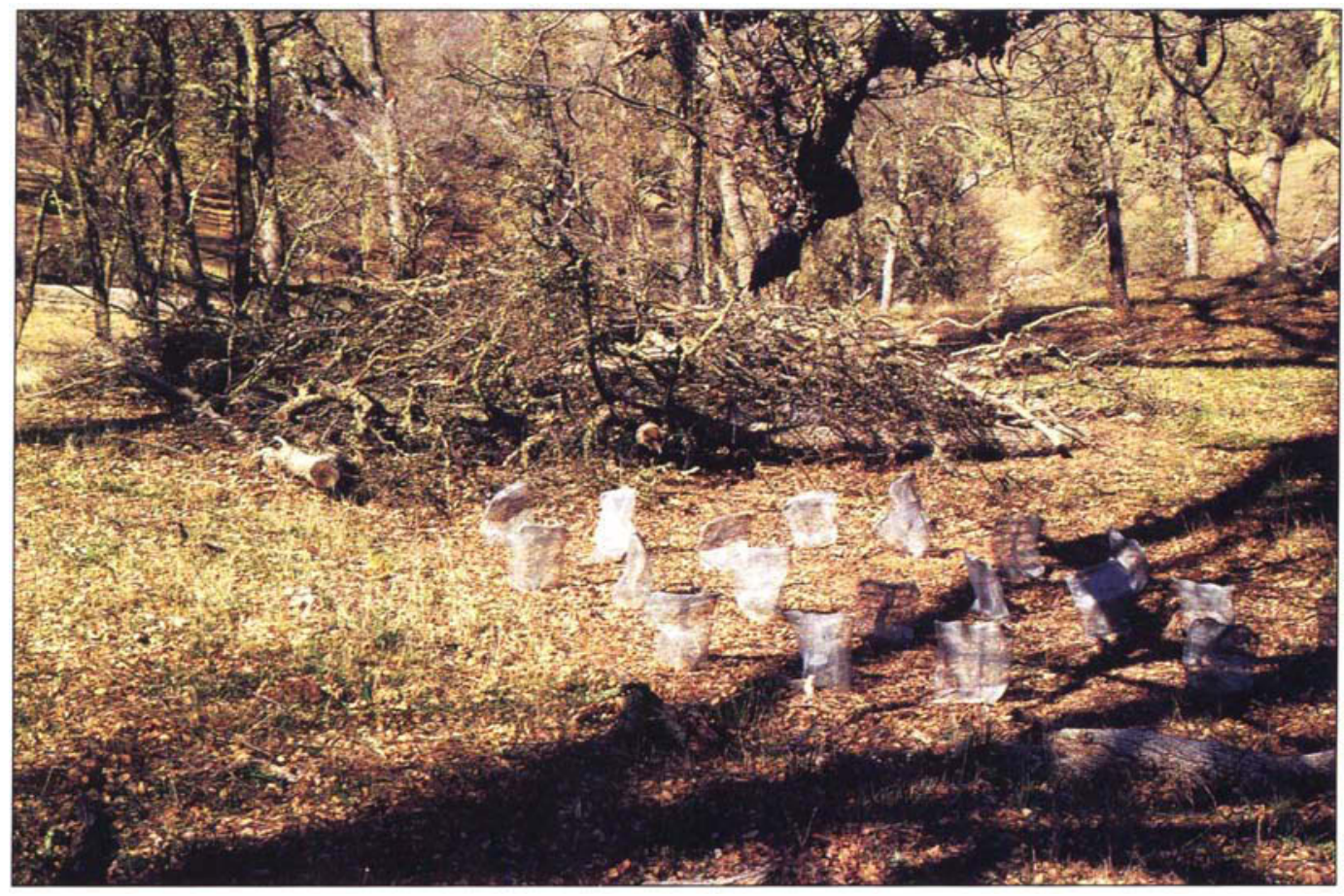

Brush piles settled down about 2 years after planting (shown February 1990), but still appeared to be excluding cattle and deer. Cages remained intact and in place, whether or not brush piles surrounded them.

southeast of Pozo, San Luis Obispo County. Annual rainfall averages about 20 inches. Herbivorous animals in the area include cattle, deer, gophers, ground squirrels, mice and cottontail rabbits. Cattle graze here about 6 months of the year and use prominent trails near the plots. This is a popular but remote deer-hunting area with a campground for hunters about one-half mile away. Gophers are numerous, as evidenced by their mounds.
We selected three planting sites, approximately 150 feet apart under partial oak canopy. In each site, 80 holes in 1-foot-by-2-foot spacings were seeded Dec. 17 to Dec. 21, 1987. Three acorns were seeded in each hole and covered with about 1.5 inches of soil.

Forty of the seeded holes in each site were covered loosely with branches and small trunks cut from blue oak trees in a nearby stumpsprouting study. The lower branches or trunks, which were 6 to 8 inches in diameter, were placed around the edges of the seeded areas and covered with smaller branches. The resulting brush piles were roughly 15 feet square and 4 to 6 feet tall. They were stacked loosely enough to allow sunlight to reach the seedlings.

To test whether additional protection was needed from small animals, cages made of aluminum window screening were installed over half of the seeded holes. Alternate holes were fitted with 6inch-diameter cages that were buried 6 inches deep to protect from gophers. The cages extended 12 inches above ground and were folded over at the top to exclude insects. A glyphosate herbicide treatment (Roundup) was applied to all plots on Jan. 27, 1988 to remove competing growth. The seedlings were shielded from the herbicide spray. Planting locations with multiple seedlings were thinned to one seedling per hole on July 1, 1988.

Growth and survival data were collected at approximately annual intervals from 1988 to 1999 . The general linear models procedure (PROC GLM) in the Statistical Analysis System (SAS 1988:549-640) was used to conduct two-way analyses of variance within each time period to test for effects of
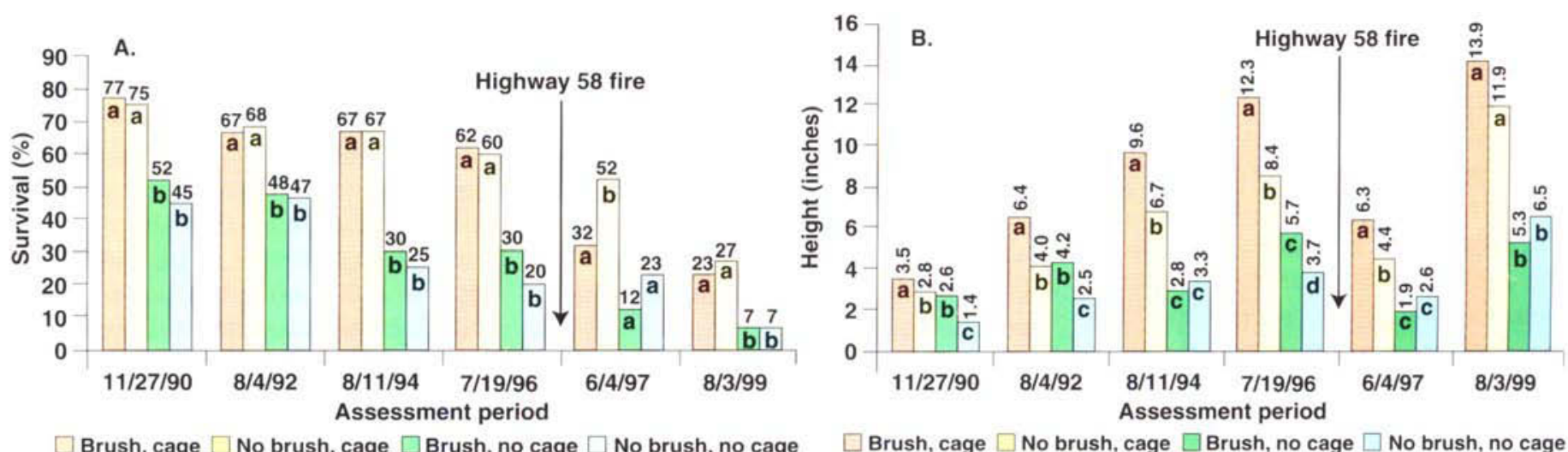

Fig. 1. Effect of brush-pile and cage treatments on survival (A) and growth (B) of blue oaks seeded December 1987. Columns with different letters (i.e., $a, b$ or $c$ ) for a given assessment period are significantly different $(P \leq 0.05)$ by Duncan's multiple-range comparison test. 
the brush and cage treatments. Treatment means were compared using a Duncan's multiple-range test and were considered significant when $P \leq 0.05$. Due to high seedling mortality in later years of the trial, the sample size became too small to use the three sites as experimental replicates in the statistical analysis. Data were therefore pooled across the three sites for all analyses.

\section{Brush piles}

The brush piles appeared to remain free of cattle and deer until 1996. There was no evidence of large animals invading the brush, even though cattle were in the trial area about 6 months each year and deer were present yearround. Trampling of the brush would have been noticeable because the oak branches were brittle, and most were small in diameter and piled in a "log cabin" formation that could have been broken down easily by large animals. Bending of aluminum cages, another sign of large animals, was also absent in all the brush piles. The brush piles settled to a height of approximately 1 to 2 feet and remained in place for 8.5 years.

Although large animals apparently were not attracted to the small seedlings in the brush piles, nor was large animal damage observed in the planting areas outside the brush piles, a far different observation was made in a stump-sprouting trial located in the immediate area of the brush-pile trial. Here, sprouts on blue oak stumps, up to 3 feet high, were browsed much more completely outside a deer- and cattle-proof fence than sprouts that were on stumps inside the fence (McCreary et al. 1991). We assumed, therefore, that seedlings were not as attractive as the succulent stump sprouts to deer and/or cattle and that browsing evidence observed on uncaged seedlings in the brush piles was caused by small mammals such as rabbits and squirrels.

\section{Seedling survival}

Survival was defined as at least one live tree from the three acorns planted in each hole. No significant differences were detected between the seedlings

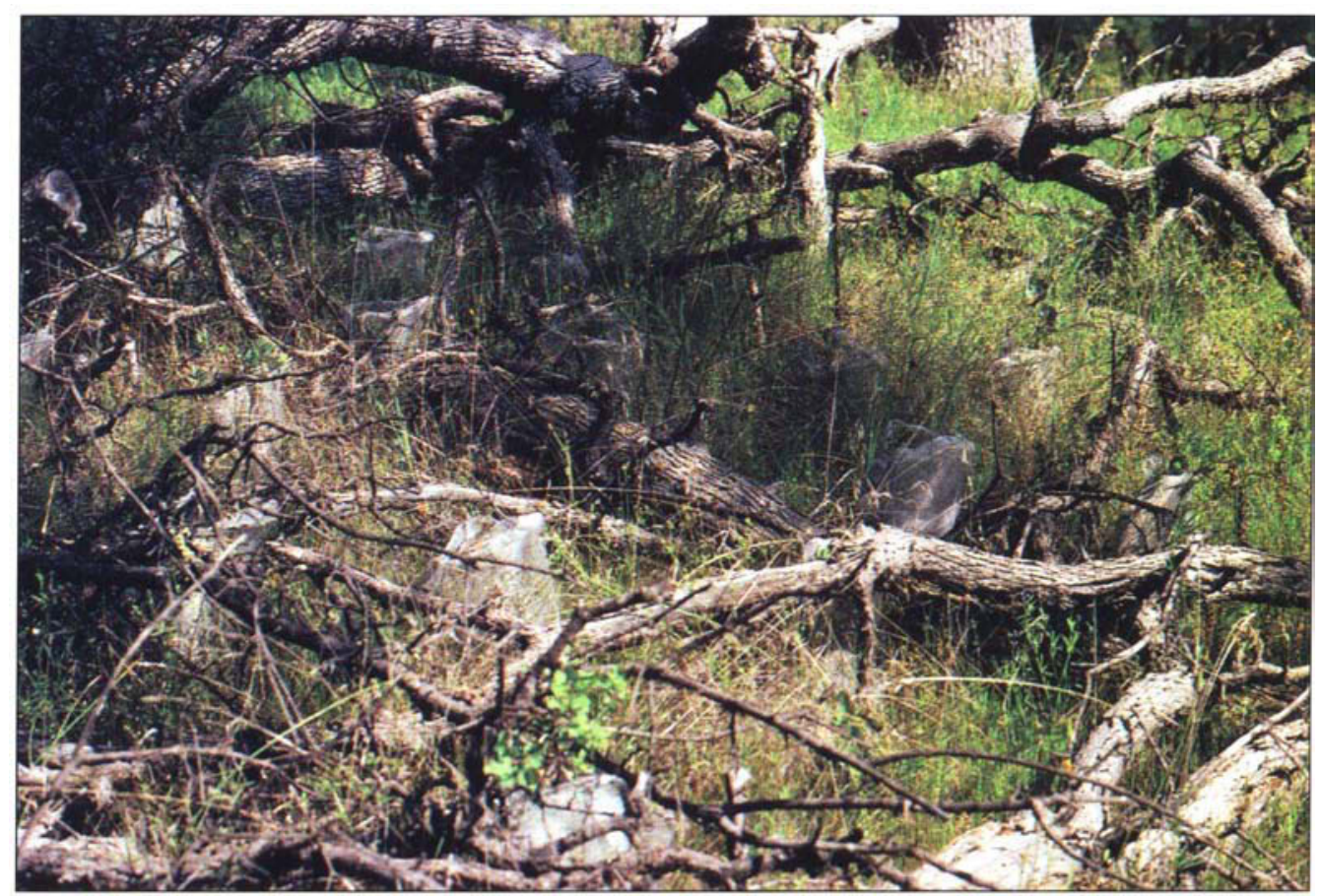

Above, A seedling was growing in each of the cages as of April 1996, 4 months before all three planting sites burned in the Highway 58 wildfire. Below, Vegetation in two of three brush piles burned to a white ash, background, by the wildfire, while combustion in no-brush plantings, foreground, was less complete.

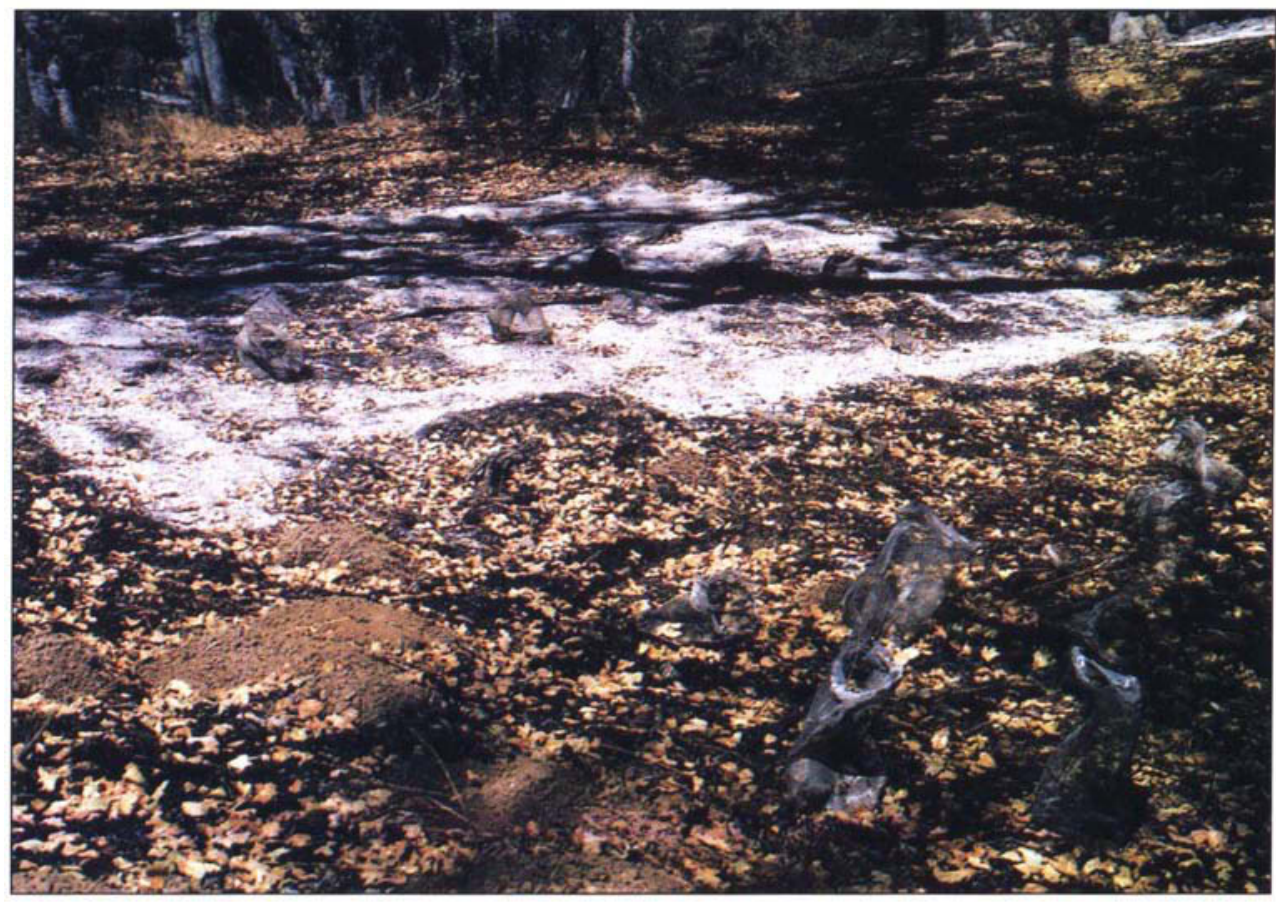

covered with brush piles or those in the open, for both caged and uncaged trees between 1990 and 1996 (fig. 1A). This was attributed to a lack of largeanimal damage in all plots, and does not prove that the brush failed to protect against large animals. There was, however, a significant survival advan- tage provided by cage protection, whether in or out of the brush piles, during this period.

In August 1996, the brush piles were consumed by the Highway 58 wildfire at all three sites. This fire started in a campground about 16 miles away and burned 106,600 acres 


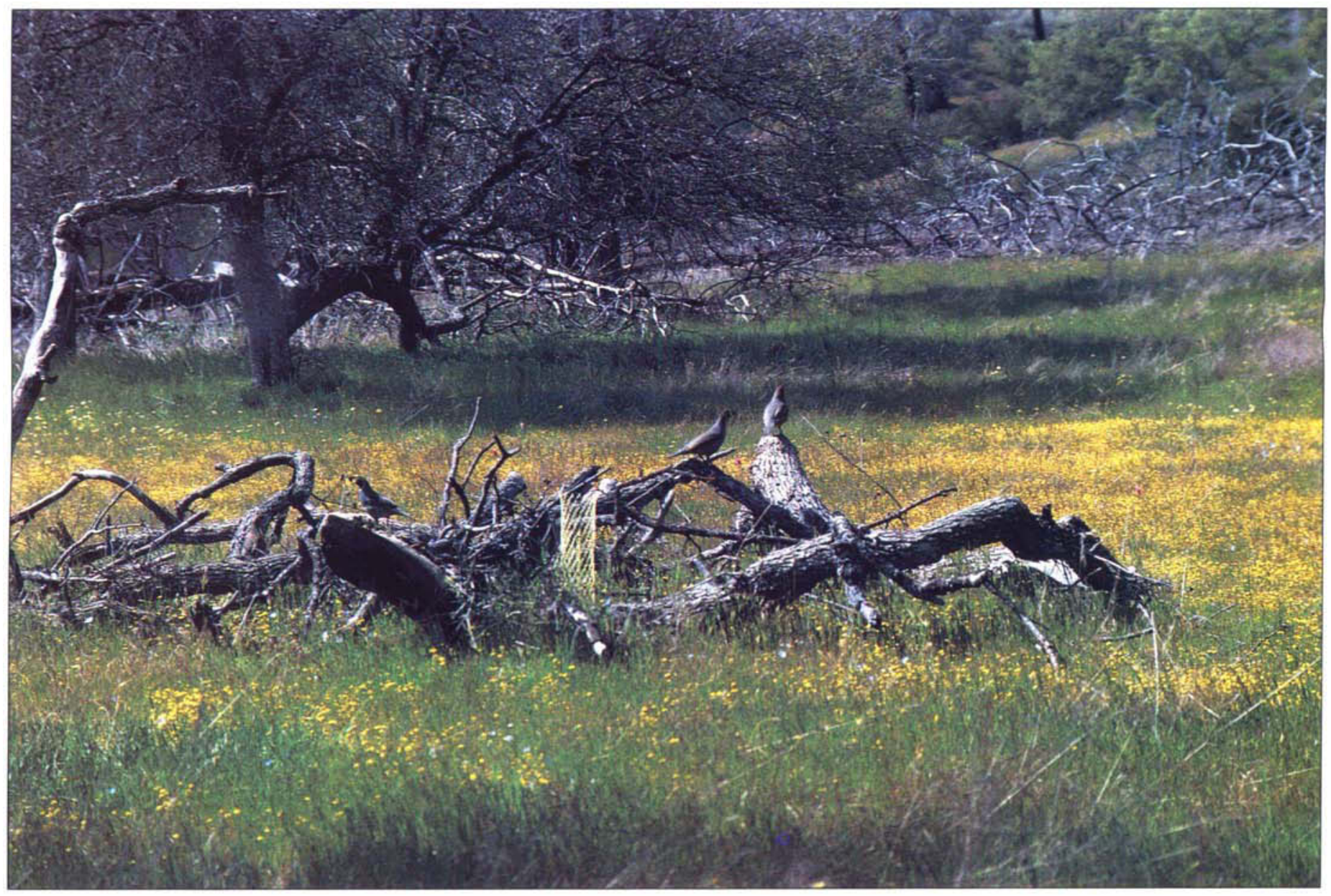

Quail are attracted to brush piles, like this small one at a different research site in San Luis Obispo County.

in a few days. Fire temperatures were higher in the brush plots, as shown by white ash from the oak branches, than in the no-brush plots, where there was lighter fuel, primarily of grasses.

Consequently, survival in the brush plots dropped sharply from $62 \%$ just before the fire to $32 \%$ one year after the fire (1997) among caged trees and from $30 \%$ to $12 \%$ among uncaged trees. In the no-brush plots, however, caged trees were reduced only moderately, from $60 \%$ to $52 \%$, and uncaged trees increased from $20 \%$ to $23 \%$ due to resprouting.

Survival for all treatment groups declined for the next 2 years (until 1999) and the difference between brush and no-brush treatments nearly disappeared. This was due mainly to the unexplained deaths of 23 of 27 seedlings in the no-brush plots at one site during this time. But caged trees still held a significant survival advantage in 1999 (23\% brush and $27 \%$ no brush) compared to uncaged ones ( $7 \%$ brush and $7 \%$ no brush).

\section{Seedling growth rates}

Figure 1B shows the average height of live trees during six assessment periods between 1990 and 1999. Height increased slowly in all four groups from 1990 until 1996, then dropped sharply when the trees were burned by the Highway 58 fire. By 1999, average height was greater than prefire levels for all except the brush, no-cage trees, which had not quite returned to the prefire height of 5.7 inches.

The average height of brush, cageprotected trees was significantly greater than the no-brush, cage trees during the first five assessment periods. This may be due to modified growth conditions such as temperature and soil moisture in the brush piles.

In all five assessment periods, cages allowed significant increases in aver- age tree height, whether in or out of the brush. This cage effect appeared to be due to protection from small animals because there was no sign of large animals invading the brush piles.

\section{Aluminum cages}

In addition to protecting trees from small animals, the cages probably would have been effective for 5 years or longer against the threat of large animals and insects. Since the only obvious signs of large animal impacts in the entire trial were a few bent cages in the no-brush plots, however, we can't say that the cages reduced seedling damage from large animals. Even in the drought years of this study, the small seedlings, protected or not, apparently were of no attraction to cattle and deer in this large, moderately grazed pasture. We also can't say that the cages were effective against large numbers of grasshoppers since there was no evidence of a grasshopper out- 
break during the trial. But the cages remained intact and sealed until the trees reached about 10 inches and near the top of the cages or until the destructive fire of 1996. Due to the slow growth rate of the trees, we did not open the cages at the top until after about the fifth growing season (summer 1992) when a few trees had grown taller than 10 inches.

Heat from the fire destroyed the aluminum of many of the cages making them ineffective against rabbits, squirrels, mice, deer and livestock. Only $25 \%$ of the cages in the brush treatments and $70 \%$ of the cages in the no-brush treatments were intact by 1999. Underground protection may also have been reduced, allowing gophers to damage tree roots. It appeared that the fire directly weakened or killed some trees and, by destroying the protective cages, also led indirectly to later mortality due to animals. In one site, however, the fire burned with only moderate intensity, leaving small amounts of white ash. Here, 13 of 16 trees survived from 1996 to 1999,3 years after the fire, and 12 of the 13 survivors still had intact cages in 1999.

\section{Brush pile options}

Since it could not be shown that cattle and deer were factors in the survival of blue oak seedlings in this trial, the only significant advantage of the brush piles was an increased seedling growth rate before the fire. In other oak planting locations, however, it has been observed that cattle can affect seedling survival by knocking over support posts, growth tubes and cages and trampling or eating seedlings. In locations where excluding cattle and deer is necessary for seedling protection, testing brush piles as a low-cost protection method may be worthwhile if downed tree branches are available.

The sharp decline in survival rates of trees in the brush piles following the fire and the thick white ash in two brush plots demonstrated that brush can burn with intense heat. Although survival differences between brush and no-brush plots leveled off statistically by the third year after the fire, hot burning brush should still be considered a liability to young oak trees.
Management options to reduce this threat include arranging the brush so it isn't as close to the trees, reducing herbaceous vegetation in and around the piles and using translucent plastic growth tubes to speed tree growth enough that brush can be removed in a few years, thereby lessening the likelihood of fire damage.

\section{Slow growth of blue oaks}

The very slow growth rate of the blue oaks in this trial, even in the cage treatments, may be partly due to the 4 years of drought in San Luis Obispo County between 1987 and 1993. Yet much faster growth rates were measured during this period for blue oaks in regeneration trials in a more arid area about 15 miles north of the Avenales Ranch. The absence of tree canopy at this drier location allowed for more sunlight to reach the seedlings and may have caused the faster growth. Follow-up herbicide treatment (Muick 1991; Swiecki et al. 1996) for several years after planting might also have accounted for the greater growth rate in the drier location, where it was shown that weed control can double the growth rate of oak seedlings (Adams et al. 1996).

The growth rate of natural blue oak seedlings outside the experimental plots at the Avenales Ranch was observed to be no greater than in the plots. This was true even inside an adjoining blue oak stump-sprouting trial area enclosed by a cattle- and deerproof fence. The natural growth rate of blue oaks at this location, in spite of an average annual rainfall of about 20 inches, is apparently less than 1 inch per year.

In summary, we determined in this trial that:

Protecting seedlings with aluminum cages significantly increased growth and survival.

- Brush piles may or may not protect seedlings from cattle and deer since there was apparently negligible damage from these animals to either pile-protected or unprotected seedlings.

- Brush piles remained in place and apparently free of cattle and deer for 8.5 years, when a wildfire destroyed the oak branches.

- Brush piles increased the potential for greater damage to seedlings from wildfires.

- Blue oak seedling growth at this site was very slow, but the brush piles had a stimulating effect on the growth rate of seedlings, caged or not, before the fire.

We concluded from this trial that cages made of aluminum window screening effectively protect oak seedlings from damage by small animals and that brush piles made of oak branches will remain in place around the seedlings to discourage access by deer and cattle for many years. We recommend that precautions be taken to reduce the impact of wildfires on the brush piles. Since we detected a growth-stimulant effect on seedlings in the brush piles, irrespective of animal exclusion, further research on how and why brush cover per se affects oak seedling growth rate might lead to a better understanding of oak regeneration problems.

W.H. Weitkamp is Livestock and Natural Resource Advisor Emeritus, LCCE San Luis Obispo County; W.D. Tietje is Natural Resource Specialist and J.K. Vreeland z'as Staff Research Associate, Department of Environmental Science, Policy and Management, UC Berkeley. Vreeland is currently Master's Candidate, Penn State.

\section{References}

Adams TE, Sands PB, Weitkamp WH, Stanley ME. 1996. Oak seedling establishment by artificial regeneration on California rangelands. Proc. of Symposium on Oak Woodlands: March 19-22, 1996; San Luis Obispo, CA. p 213-23.

McCreary DD, Tietje WD, Schmidt RH, et al. 1991. Stump sprouting of blue oaks in California. Proc. of Symposium on Oak Woodlands and Hardwood Rangeland Man. agement: Oct 31-Nov 2, 1990; Davis, CA. p 64-9.

Muick PC. 1991. Effects of shade on blue oak and coast live oak regeneration in California annual grasslands. Proc. of Symposium on Oak Woodlands and Hardwood Rangeland Management: Oct 31-Nov 2, 1990; Davis, CA. p 21-4.

Swiecki TJ, Bernhardt EA, Drake C. 1996 Factors affecting blue oak sapling recruitment. Proc. of Symposium on Oak Woodlands: March 19-22, 1996; San Luis Obispo, CA. p 157-67. 